\title{
PASIEN PASKA STROKE PADA FASE SUBACUTE: INFORMASI YANG DIBUTUHKAN
}

\author{
Sri Hartati Pratiwi ${ }^{1^{*}}$, Eka Afrima Sari ${ }^{2}$, Ristina Mirwanti ${ }^{3}$ \\ ${ }^{1-3}$ Universitas Padjadjaran \\ Email Korespondensi: sri.hartati.pratiwi@unpad.ac.id \\ Disubmit: 23 Januari 2022 Diterima: 27 Januari 2022 Diterbitkan: 01 Februari 2022 \\ DOI: https://doi.org/10.33024/mnj.v5i2.5901
}

\section{ABSTRACT: POST STROKE PATIENTS IN THE SUBACUTE PHASE: INFORMATION REQUIRED}

Introduction: Post-stroke patient care in the subacute phase is carried out independently by the patient and family at home. Post-stroke patients must have adequate knowledge to carry out self-care at home. The lack of information obtained by post-stroke patients can affect the patient's ability to carry out self-care so that his health status decreases. Therefore, nurses as educators must be able to provide information according to the needs of poststroke patients.

Purpose: This study was conducted to determine the information needs of poststroke patients in the sub-acute phase so that the nursing care provided is in accordance with the patient's needs.

Method: This study is a quantitative descriptive study conducted on post-stroke patients at the Neurology Polyclinic, one of the hospitals in Bandung. The sample technique used was consecutive sampling as many as 83 people. The inclusion criteria of post-stroke patients in this study were having full awareness and not experiencing aphasia. The instrument used in this study was based on the concept of the needs of post-stroke patients Kevitt (2009) and Moreland (2009) with a validity coefficient of 0.73 and an $r$ of 0.75 .

Result: The information needs of post-stroke patients in a row include information about self-management to prevent recurrence or stroke recurrence $(\bar{x}=1,59)$, nformation about nutrition that must be taken $(\bar{x}=1,54)$, information about risks and side effects of treatment $(\bar{x}=1,49)$, information about certainty of disease condition $(\bar{x}=1,48)$, and information about stroke ( $\bar{x}=1,45)$.

Conclusion: Post-stroke patients need all information related to stroke, especially regarding self-management. Therefore, health workers are expected to provide education according to patient needs. Education for stroke patients can be done using various media and focuses on the patient.

Keywords: Informations needs, Subacute, Stroke Patients 


\section{INTISARI: PASIEN PASKA STROKE PADA FASE SUBACUTE: INFORMASI YANG DIBUTUHKAN}

Latar Belakang: Perawatan pasien post stroke pada fase subacute dilakukan secara mandiri oleh pasien dan keluarga di rumah. Pasien paska stroke harus memiliki pengetahuan yang adekuat untuk menjalankan perawatan diri di rumah. Kurangnya informasi yang didapatkan pasien paska stroke dapat mempengaruhi kemampuan pasien menjalankan perawatan diri sehingga status kesehatannya menurun. Oleh karena itu, perawat sebagai edukator harus mampu memberikan informasi sesuai kebutuhan pasien paska stroke.

Tujuan: Penelitian ini dilakukan untuk mengetahui kebutuhan informasi pasien paska stroke pada fase subacute agar asuhan keperawatan yang diberikan sesuai dengan kebutuhan pasien.

Metoda Penelitian: Penelitian ini merupakan penelitian deskriptif kuantitatif yang dilakukan kepada pasien paska stroke di Poliklinik Saraf dua Rumah Sakit di Bandung. Teknik sample yang digunakan adalah consecutive sampling sebanyak 83 orang. Kriteria inklusi pasien paska stroke dalam penelitian ini adalah memiliki kesadaran penuh dan tidak mengalami aphasia. Instrumen yang digunakan dalam penelitian ini disusun berdasarkan konsep kebutuhan pasien paska stroke khususnya bagian kebutuhan informasi yang dikembangkan oleh Kevitt (2009) dan Moreland (2009) dengan koefisien validitas 0,73 dan r 0,75.

Hasil: Kebutuhan informasi pasien paska stroke secara berturut-turut diantaranya adalah informasi mengenai manajemen diri untuk mencegah kekambuhan atau stroke ulang $(\bar{x}=1,59)$, informasi mengenai nutrisi yang harus dijalani $(\bar{x}=1,54)$, informasi mengenai resiko dan efek samping pengobatan $(\bar{x}$ $=1,49)$, informasi mengenai kepastian kondisi penyakit $(\bar{x}=1,48)$, dan informasi mengenai penyakit stroke $(\bar{x}=1,45)$.

Kesimpulan: Pasien paska stroke membutuhkan semua informasi yang berkaitan dengan stroke khususnya mengenai manajemen diri. Oleh karena itu, petugas kesehatan diharapkan dapat memberikan edukasi sesuai dengan kebutuhan pasien. Edukasi pada pasien stroke dapat dilakukan dengan menggunakan berbagai media dan berfokus pada pasien.

Kata Kunci : Kebutuhan informasi, Pasien Stroke, subacute

\section{PENDAHULUAN}

Stroke merupakan salah satu penyebab kematian utama di berbagai negara di dunia. Angka kejadian stroke terbanyak di Asia adalah di Indonesia. Penderita stroke di Indonesia terus bertambah setiap tahunnya. Berdasarkan data yang diperoleh dari hasil Riset Kesehatan Dasar (Riskesdas) tahun 2013, angka kejadian stroke di Indonesia terus meningkat menjadi 12,1 per 1000 penduduk jika dibandingkan dengan riskesdas tahun 2007 yang hanya mencapai 8,3 per
1000 penduduk (Kementerian Kesehatan RI, 2014).

Stroke adalah suatu keadaan dimana sel-sel otak mengalami kerusakan karena kekurangan oksigen yang disebabkan oleh adanya gangguan aliran darah ke otak. Stroke dibagi menjadi dua kategori diantaranya adalah stroke iskemik (85\%) dan stroke hemoragik (15\%). Apabila aliran darah ke otak mengalami gangguan, maka otak akan mengalami kekurangan oksigen. Hal ini akan menyebabkan gangguan fungsi di bagian otak tersebut yang dapat menimbulkan 
gangguan fisik dalam jangka waktu yang panjang bahkan kematian. Gangguan fungsi otak yang dialami pasien paska stroke dapat berupa gangguan fisik, gangguan emosional, dan gangguan kognitif (Smeltzer and Bare, 2010).

Gangguan fisik, gangguan emosional serta gangguan kognitif yang dialami pasien stroke membutuhkan perawatan dalam jangka waktu yang lama. Gangguan fisik yang sering dialami diantaranya adalah kelemahan anggota gerak, gangguan menelan, gangguan berbicara dan lain-lain. Gangguan emosional sering dirasakan oleh pasien paska stroke, tetapi $73 \%$ diantaranya tidak mendapatkan bantuan dalam mengatasi masalah tersebut. Sebagian besar pasien paska stroke merasakan kelelahan dan $43 \%$ diantaranya tidak mendapatkan bantuan untuk mengatasinya. Gangguan psikologis pada pasien stroke dapat berupa kecemasan dan depresi (Kevitt et.al., 2009).

Berdasarkan waktu dari serangannya, stroke dibagi menjadi beberapa fase, yaitu fase inisial atau akut, fase subacute dan fase perawatan kronik. Fase subacute dimulai setelah fase akut (dua minggu) sampai enam bulan setelah serangan stroke (Kiran, S., 2012). Pada Fase subacute, kondisi pasien mulai stabil. Pada fase ini, pasien biasanya diperbolehkan pulang dari rumah sakit dan dilanjutkan dengan rawat jalan untuk menangani gejala sisa yang dialaminya seperti gangguan pergerakan, gangguan menelan, gangguan berbicara dan lain-lain. Berbeda dengan fase sebelumnya, perawatan pasien pada fase rehabilitasi tidak lagi sepenuhnya dilakukan oleh tenaga kesehatan. Perawatan dan pemenuhan kebutuhan pasien dilakukan secara mandiri atau dibantu oleh keluarga (Wirawan,
2009). Pasien paska stroke harus menjalankan manajemen diri dengan baik. Berdasarkan penelitian yang dilakukan Rahmawati et al tahun 2019, sebanyak 47,5\% pasien paska stroke di Rumah Sakit yang sama pada penelitian ini memiliki self-management yang buruk.

Untuk menjalankan manajemen diri di rumah, pasien stroke harus memiliki bekal pengetahuan yang adekuat. Berdasarkan penelitian yang dilakukan oleh Koutnik tahun 2014, sebagian besar pasien paska stroke memiliki literasi kesehatan yang tidak adekuat. Pasien paska stroke yang memiliki literasi kesehatan buruk akan berakibat pada penurunan status kesehatan (Sanders, et al., 2014). Sebaliknya, jika pasien memiliki literasi kesehatan yang baik dapat membentuk perilaku yang sesuai sehingga kualitas hidupnya akan meningkat (Martins et al., 2016). Oleh karena itu, pemberian informasi pada pasien paska stroke sebagai persiapan perawatan di rumah sangat penting.

Perawat memiliki peran yang sangat penting dalam memberikan edukasi pada pasien paska stroke. Perawat harus memberikan edukasi secara berkesinambungan. Berbagai metode edukasi sudah dilakukan untuk memberikan informasi kepada pasien paska stroke pada fase rehabilitasi, tetapi sebagian besar pasien merasakan kebutuhan informasi yang belum terpenuhi (Davoody et al, 2016). Hal ini bisa disebabkan karena informasi yang diberikan tidak sesuai kebutuhan pasien. Sehingga penelitian ini dilakukan untuk menjawab pertanyaan "Apakah informasi yang dibutuhkan pasien paska stroke pada fase subacute?". Penelitian ini diharapkan dapat menjadi dasar bagi perawat dalam memberikan edukasi 
kepada pasien paska stroke pada fase subacute.

\section{METODOLOGI PENELITIAN}

$\begin{array}{llr} & \text { Metode yang digunakan } \\ \text { dalam penelitian ini } & \text { adalah } \\ \text { deskriptif } & \text { kuantitatif } & \text { dengan } \\ \text { pendekatan } & \text { crossectional } & \text { survey. }\end{array}$
Penelitian ini dilakukan pada pasien paska stroke di poliklinik dan stroke centre di dua Rumah Sakit di Bandung. Sampel dalam penelitian ini diambil dengan consecutive sampling, dengan jumlah sampel 83 orang. Kriteria inklusi dalam penelitian ini adalah pasien paska stroke yang memiliki kesadaran penuh dan tidak mengalami aphasia. Kriteria ekslusi dalam penelitian ini adalah pasien stroke yang tidak stabil dengan tekanan darah tinggi.

Teknik pengumpulan data yang digunakan oleh peneliti untuk mendapatkan data yang diharapkan adalah metode kuesioner atau angket. Karakteristik responden dikaji untuk melihat homogenitas dan faktor lain yang berpengaruh pada kondisi pasien yang teridiri dari data usia, jenis kelamin, pendidikan terakhir, lama menderita stroke serta riwayat stroke sebelumnya.

Instrumen Kebutuhan paska stroke yang digunakan dalam penelitian ini disusun berdasarkan konsep kebutuhan pasien paska stroke khususnya bagian kebutuhan informasi yang dikembangkan oleh Kevitt (2009) dan Moreland (2009). Kuesioner kebutuhan pasien paska stroke yang digunakan menggunakan skala likert yang terdiri dari pertanyaan tertutup dengan 4 opsi jawaban. Klasifikasi kebutuhan didasarkan kepada : hal tersebut tidak menjadi masalah dan pasien tidak membutuhkan bantuan atau kebutuhan tersebut telah bisa diatasi oleh pasien (diberi nilai 0 ).
Kebutuhan tingkat rendah berarti pasien merasakan ketidaknyamanan dengan hal tersebut dan membutuhkan sedikit bantuan tambahan untuk mengatasinya (nilai 1). Kebutuhan tingkat menengah berarti pasien merasakan ketidaknyamanan dengan hal tersebut dan membutuhkan beberapa bantuan untuk mengatasinya (diberi nilai 2). Kebutuhan tingkat tinggi apabila pasien merasakan ketidaknyamanan dengan hal tersebut dan membutuhkan banyak bantuan untuk mengatasinya (diberi nilai 3 ). Uji validitas terhadap kuesioner ini dilakukan dengan uji content validity dan construct validity. Berdasarkan jumlah responden yang digunakan dalam uji validitas ini yaitu sebanyak 10 responden, dan semua item dinyatakan valid dengan koefisien validitasnya $>0,632$ dan $r$ $>0,75$ sehingga dinyatakan valid dan reliable.

Data yang terkumpul dianalisa dengan menggunakan analisa deskriptif yaitu dengan frekuensi, persentase dan mean. Data setiap item akan dianalisa dengan menggunakan mean. Informasi pasien paska stroke yang paling dibutuhkan diurutkan berdasarkan mean. Item kebutuhan dikatakan dibutuhkan apabila nilai mean per item $>1$.

\section{HASIL PENELITIAN}

Data responden dikumpulkan untuk melihat karakteristik responden. Data tersebut terdiri dari usia, jenis kelamin, pendidikan terakhir, riwayat stroke sebelumnya, serta lama menderita stroke. Karakteristik responden dalam penelitian ini dapat dilihat pada tabel 1. 
Tabel 1. Karakteristik Responden

\begin{tabular}{lccc}
\hline & Usia & Frekuensi (f) & Persentase (\%) \\
\hline$>55$ tahun & 38 & 45,8 \\
\hline $17-25$ tahun & 0 & 0 \\
\hline $26-35$ tahun & 0 & 0 \\
\hline $36-45$ tahun & 3 & 3,6 \\
\hline $46-55$ tahun & Jenis Kelamin & 42 & 50,6 \\
\hline \multicolumn{1}{c}{ Laki-laki } & Frekuensi (f) & Persentase (\%) \\
\hline Perempuan & 48 & 57,8 \\
\hline \multicolumn{1}{c}{ Pendidikan } & 35 & 42,2 \\
\hline Tidak sekolah & Frekuensi (f) & Persentase (\%) \\
\hline SD/ Sederajat & 1 & 1,2 \\
\hline SMP/ Sederajat & 12 & 14,5 \\
\hline SMA/Sederajat & 11 & 13,4 \\
\hline Perguruan Tinggi & 34 & 41 \\
\hline \multicolumn{1}{c}{ Riwayat stroke Sebelumnya } & 25 & 31 \\
\hline Stroke pertama & Frekuensi (f) & Persentase (\%) \\
\hline Stroke ulang & 67 & 80,7 \\
\hline \multicolumn{1}{c}{ Lama Stroke } & 16 & 19,3 \\
\hline$<3$ Bulan & Frekuensi (f) & Persentase (\%) \\
\hline $3-6$ bulan & 13 & 15,7 \\
\hline 7 - 12 bulan & 10 & 12 \\
\hline 1-2 tahun & 21 & 25,3 \\
\hline$>2$ tahun & 15 & 18,1 \\
\hline
\end{tabular}

Dari hasil penelitian dapat dilihat bahwa sebagian besar responden berada pada usia 46-55 tahun (50,6\%), laki-laki $(57,8 \%)$, memiliki pendidikan SMA/ Sederajat (41\%), stroke pertama $(80,7 \%)$, menderita stroke lebih dari 2 tahun $(28,9 \%)$.

Kebutuhan informasi pasien paska stroke pada fase subacute dalam penelitian ini dapat dilihat pada tabel 2.

Tabel 2. Kebutuhan Informasi Pasien Paska Stroke

\begin{tabular}{lccccc}
\hline $\begin{array}{l}\text { Pasien stroke } \\
\text { membutuhan } \\
\text { bantuan } \\
\text { untuk }\end{array}$ & Mean & $\begin{array}{c}\text { Tidak } \\
\text { membutuhkan/ } \\
\text { Sudah } \\
\text { terpenuhi } \\
\mathrm{F}(\%)\end{array}$ & $\begin{array}{c}\text { Kebutuhan } \\
\text { tingkat } \\
\text { rendah } \\
\mathrm{F}(\%)\end{array}$ & $\begin{array}{c}\text { Kebutuhan } \\
\text { tingkat } \\
\text { menengah } \\
\mathrm{F}(\%)\end{array}$ & $\begin{array}{c}\text { Kebutuhan } \\
\text { tingkat } \\
\text { tinggi } \\
\mathrm{F}(\%)\end{array}$ \\
\hline $\begin{array}{l}\text { Mendapatkan } \\
\text { informasi } \\
\text { mengenai }\end{array}$ & 1,45 & $17(20,5 \%)$ & $27(32,5 \%)$ & $24(28,9 \%)$ & $15(18,1 \%)$ \\
$\begin{array}{l}\text { penyakit } \\
\text { stroke }\end{array}$ & & & & & \\
\hline $\begin{array}{l}\text { Informasi } \\
\text { mengenai }\end{array}$ & 1,49 & $13(15,7 \%)$ & $31(37,3 \%)$ & $24(28,9 \%)$ & $15(18,1 \%)$ \\
resiko dan \\
efek samping
\end{tabular}




\begin{tabular}{|c|c|c|c|c|c|}
\hline $\begin{array}{c}\text { Pasien stroke } \\
\text { membutuhan } \\
\text { bantuan } \\
\text { untuk }\end{array}$ & Mean & $\begin{array}{c}\text { Tidak } \\
\text { membutuhkan/ } \\
\text { Sudah } \\
\text { terpenuhi } \\
\text { F(\%) }\end{array}$ & $\begin{array}{c}\text { Kebutuhan } \\
\text { tingkat } \\
\text { rendah } \\
\mathrm{F}(\%)\end{array}$ & $\begin{array}{c}\text { Kebutuhan } \\
\text { tingkat } \\
\text { menengah } \\
\mathrm{F}(\%)\end{array}$ & $\begin{array}{c}\text { Kebutuhan } \\
\text { tingkat } \\
\text { tinggi } \\
\mathrm{F}(\%)\end{array}$ \\
\hline $\begin{array}{l}\text { Informasi } \\
\text { mengenai } \\
\text { nutrisi yang } \\
\text { harus dijalani }\end{array}$ & 1,54 & $10(12 \%)$ & $35(42,2 \%)$ & $21(25,3 \%)$ & $17(20,5 \%)$ \\
\hline $\begin{array}{l}\text { Informasi } \\
\text { mengenai } \\
\text { manajemen } \\
\text { diri untuk } \\
\text { mencegah } \\
\text { kekambuhan } \\
\text { atau stroke } \\
\text { ulang }\end{array}$ & 1,59 & $12(14,5 \%)$ & $28(33,7 \%)$ & $25(30,1 \%)$ & $18(21,7 \%)$ \\
\hline $\begin{array}{l}\text { Informasi } \\
\text { mengenai } \\
\text { kepastian } \\
\text { kondisi } \\
\text { penyakit }\end{array}$ & 1,48 & $20(24,1 \%)$ & $23(27,7 \%)$ & $20(24,1 \%)$ & $20(24,1 \%)$ \\
\hline
\end{tabular}

\section{PEMBAHASAN}

Kebutuhan informasi merupakan kebutuhan yang dirasakan oleh pasien paska stroke. Hal ini dapat dilihat dari nilai mean disemua item pertanyaan > 1 . Kebutuhan informasi yang dirasakan pasien berturut-turut adalah informasi mengenai manajemen diri untuk mencegah kekambuhan atau stroke ulang, informasi mengenai nutrisi yang harus dijalani, informasi mengenai resiko dan efek samping pengobatan, informasi mengenai kepastian kondisi penyakit, dan informasi mengenai penyakit stroke. Semua informasi tersebut sangat penting untuk mencapai outcome fase sub-acute.

Informasi manajemen diri untuk mencegah kekambuhan sangat diperlukan untuk mengontrol faktor resiko stroke seperti hipertensi dan diabetes mellitus sehingga tidak terjadi stroke ulang. Pasien stroke harus memiliki tanggung jawab diri dalam menjalankan fase rehabilitasi terutama dalam manajemen diri untuk mengontrol penyakitnya dan mencegah stroke berulang (Morais et.al., 2014). Program manajemen diri untuk penderita stroke dapat mencakup pendidikan khusus tentang stroke dan kemungkinan efeknya, tetapi pada dasarnya juga berfokus pada pelatihan keterampilan untuk mendorong pasien mengambil bagian aktif dalam manajemen mereka sendiri. Pelatihan keterampilan tersebut dapat mencakup pemecahan masalah, penetapan tujuan, pengambilan keputusan, dan keterampilan mengatasi nyeri (Fryer, et al.,2016). Informasi lain yang dibutuhkan oleh pasien paska stroke adalah terkait dengan nutrisi yang harus dijalani oleh pasien stroke. Nutrisi sangat penting dan berpengaruh pada pasien paska stroke. Beberapa jenis makanan dapat memperburuk kondisi pasien. Berbagai penelitian menunjukan bahwa angka kematian pada pasien stroke dapat meningkat pada pasien 
dengan asupan garam. kolesterol dan lemak yang tinggi. Pasien paska stroke dengan status gizi obesitas dapat memperberat beban kerja jantung. Selain itu, terdapat berbagai jenis nutrisi sangat dibutuhkan pasien paska stroke seperti protein, sayuran hijau, dan mikronutrien yang lain dapat meningkatkan kondisi kesehatan pasien paska stroke (Huang, 2007). Berbagai informasi tersebut sangat dibutuhkan oleh pasien sehingga dapat meningkatkan pencapaian terhadap tujuan rehabilitasi dan pemulihan.

Informasi mengenai penyakit stroke, perawatan yang harus dijalani beserta dengan efek samping yang dapat dialami pasien sangat diperlukan oleh pasien paska stroke dalam penelitian ini. Pengetahuan terkait hal tersebut merupakan dasar bagi pasien untuk menjalankan manajemen dirinya di rumah. Selain itu, pengetahuan yang adekuat mengenai penyakit stroke dan perawatanya dapat mengurangi kecemasan pada pasien (HyoungSook, 2013). Informasi yang cukup mengenai stroke dan perawatannya dapat memberikan motivasi pada pasien untuk menjalani program pemulihan yang sudah ditetapkan sebelumnya sehingga kecemasan pasien dapat menurun. Selain itu, World Health Organization (WHO) juga menyatakan bahwa semua pasien berhak menerima informasi tentang kondisi kesehatannya yang faktual, mudah dipahami, akurat, dan sesuai dengan kebutuhannya (Knight et al, 2006).

Jika dibandingkan dengan karakteristik responden yang sebagian besar sudah mengalami stroke lebih dari 2 tahun, seharusnya responden sudah memiliki pengetahuan yang adekuat tentang penyakit stroke, perawatan yang harus dijalani, manajemen diri, nutrisi dan efek samping pengobatan. Namun berdasarkan hasil penelitian ini, responden masih membutuhkan bantuan untuk memperoleh informasi tersebut. Oleh karena itu, perlu dikaji lagi apa yang menyebabkan responden masih membutuhkan informasi terkait hal tersebut.

Pemenuhan kebutuhan informasi pada pasien paska stroke dapat dilakukan dengan memberikan edukasi yang terstruktur dan berfokus pada pasien. Pasien paska stroke diharapkan memiliki peran aktif dalam proses edukasi untuk memenuhi kebutuhan mereka sendiri. Selain itu, terdapat berbagai metode edukasi yang sudah dikembangkan khusus untuk pasien stroke yang sangat dimungkinkan mengalami berbagai keterbatasan fisik, maupun kognitif. Salah satunya adalah edukasi kesehatan berbasis internet (Davoody et al, 2016)

Tujuan dari dilakukannya edukasi pada pasien stroke adalah pasien dan pemberi perawatan memiliki panduan dan pengetahuan untuk mengontrol faktor risiko stroke dan segera mencari pertolongan petugas kesehatan apabila terdapat gejala kekambuhan atau serangan stroke ulang. Pemberian edukasi pada pasien paska stroke dapat dilakukan dengan menggunakan berbagai strategi diantaranya adalah dengan menggunakan media tertulis, bergambar atau media audio visual agar materi edukasi dapat diberikan secara maksimal meskipun pasien memiliki keterbatasan fisik (Griffin et al, 2012).

\section{KESIMPULAN}

Berdasarkan penelitian ini, informasi yang paling dibutuhkan pasien paska stroke pada fase subacute adalah informasi mengenai manajemen diri untuk mencegah kekambuhan atau stroke ulang. Oleh 
karena itu, petugas kesehatan khususnya perawat dapat memberikan informasi tersebut secara berkesinambungan dengan menggunakan berbagai metode dan media serta mempertimbangkan keterbatasan yang dimiliki oleh pasien stroke.

\section{DAFTAR PUSTAKA}

Davoody,N., Koch,S., Krakau,I., Hagglund, M. (2016). Postdischarge stroke patients' information needs as input to proposing patient- centred eHealth services. BMC Medical Informatics and Decision Making. Vol.16. No. 66. DOI 10.1186/s12911-016-0307-2. https: / /bmcmedinformdecism ak.biomedcentral.com

Fryer, Luker, McDonnell, Hillier. (2016). Self-Management Programs for Quality of Life in People With Stroke. Stroke. Vol. 2016 No 47: e266-e267. https://doi.org/10.1161/STRO KEAHA.116.015253. Www.ahajournal.org.

Fure,B., Wyller.,T.B.,Engedal,K. and Thommessen, B. (2006). Emotional Symptoms In Acute Ischemic Stroke. Int.J.Geriat. Psychiatry ; 21 : 382 -387. doi : 10.1002/gps.1482. available at

www.onlinelibrary.willey.com Godbout. Goldberger. Dupont.Mansour. Rosenthal. Robert. (2015). Secondary Stroke Prevention Information For Patients and Families. available at www.strokengine.ca

Griffin, L. and Hickey,J. (2013). Considerations and strategies for educating stroke patients with neurological deficits. Journal of Nursing Education and Practice. Vol. 3 No. 8: 125 $-137$. http://dx.doi.org/10.5430/jn

ep.v3n8p125

www.sciedu.ca/jnep

Huang, Chen Ya. (2007). Nutrition and Stroke. Asia Pacific Journal Clinical Nutrition. vol 16 (suppl 1): 266-274. available at www.pdfs.semanticscholar.or $\mathrm{g}$

Hyoung-Sook, P., Mee-Hun, L., JaeHyun, H.(2013). The Effects of Individualized Education on Stroke Patients' Post-discharge Anxiety and Self-care Compliance. The Korean Journal of Rehabilitation Nursing. Vol. 16: 1-8. https://doi.org/10.7587/kjreh n.2013.1

Kementerian Kesehatan Republik Indonesia. 2014. InfoDatin. Situasi Kesehatan Jantung. Jakarta : Pusat Data dan Informasi Kemenkes RI.

Koutnik-Fotopoulos, E. (2014). Correlation between Health Literacy and Stroke Education Outcomes. Global Learning Network.

https://www.hmpgloballearni ngnetwork.com

Kevitt, Fudge, Redfern, Sheldenkar, Chrichton, Wolfe. (2009). The Stroke Survivor Needs Survey. London : King's College London. diunduh dari www.nao.org.uk

Knight, K., Worrall,L. Rose,T. (2006). The Provision of Health Information to Stroke Patients Within an Acute Hospital Setting: What Actually Happens and How Do Patients Feel About It?. Topics In Stroke Rehabilitation. Vol 13. No 1: 78 97. https: / / espace.library.uq.edu .au

Morais. Gonzaga. Aquino. Araujo. (2014). Strategies for SelfManagement Support by 
Patients with Stroke : Integrative Review. Journal of School of Nursing. doi : 10.1590/500806234201500001 00018. vol : 2015(49) : 134141. available at www.scielo.br

Moreland, Depaul, Amy, Pangliuso, Yip, Pollock, Wilkins. (2009). Needs Assessment of Individuals with Stroke After Discharge From Hospital Stratified ny Acute Functional Independence Measure Score. Disability and Rehabilitation. Vol. 31, No 26. Hal 2185-2195.

Rahmawati,D., Kurniawan,T., Pratiwi, S.H. (2019). Gambaran Self-Management Pada Pasien Stroke Yang Menjalani Rawat Jalan. Jurnal Keperawatan Aisyiyah. Vol.6 No.

https: / /www.journal.unisabandung.ac.id

Sanders, Schnepel, Smotherman, Livingood, Dodani,....Silliman. (2014). Assessing the Impact of Health Literacy on Education Retention of Stroke Patients. Preventing Chronic Disease.Vol.11.

http://dx.doi.org/10.5888/pc d11.130259.

www.ncbi.nlm.nih.gov.

Sturm, Donnan, Dewey, Macdonnel, Gilligan, Srikant, Thrift. (2004). Quality of Life After Stroke. The North East Melbourne Stroke Incidence Study (NEMESIS). Stroke. Vol.35, Hal 2340-2345. diunduh dari stroke.ahajournal.org

Smeltzer, S.O. and Bare, B.G. (2010). Brunner \& Suddart Medical Surgical Nursing. $12^{\text {th }}$ edition. Philadelphia: Lippincott Williams and wilkins.

Tyrell and Smithard. (2006). Fatigue After Stroke. Therapy. Vol: 6:
865-869. available at www.openaccessjournals.com

Wirawan, Rosiana. (2009). Rehabilitasi Stroke Pada Pelayanan Kesehatan Primer. Majalah Kedokteran Indonesia Vol. 59 No. 2 Hal 62-71. 